\title{
Similarity in trade structures, integration and catching-up ${ }^{1}$
}

\author{
Luca De Benedictis* and Lucia Tajoli** \\ *DIEF, University of Macerata, Macerata, Italy. E-mail: debene@unimc.it \\ **Dipartimento di Ingegneria Gestionale, Politecnico di Milano, Milan, Italy. \\ E-mail: lucia.tajoli@polimi.it
}

\section{Abstract}

In this paper, we look at the role of export composition in the growth process, considering how increased similarity in trade structure among countries can induce catching-up in income levels in a group of countries in transition. We analyze the sectoral export patterns of the Central and Eastern European countries (CEECs) by comparing them to those of the current members of the European Union (EU), focusing on countries' specialization as suppliers for the EU market, and we assess whether similar export patterns foster the catching-up process of the CEECs. Our main result is that similarity in export composition has a positive, significant and non-linear impact on catching-up, and seems to be driven by the growth of the main export market and delocalization of production more than by other factors.

JEL classifications: F3, F42.

Keywords: CEECs, export composition, growth, EU enlargement.

\section{Introduction}

The effects of economic integration on the well-being of countries have been studied in economics for a long time. In many economic models the link between a

\footnotetext{
${ }^{1}$ Thanks are due to Marco Maffezzoli for his comments on a preliminary version of the paper and to the participants to the ETSG 2005 Conference in Dublin, the ATINER 2006 Conference in Athens, the European Commission economic seminars. Financial support from MIUR, PRIN prot. 2002138555 is gratefully acknowledged.
} 
country's growth rates and its level of openness hinges on the characteristics of the country's trade pattern. But in spite of the suggestions coming from theoretical models (Baldwin, 2004), most of the empirical literature limits the analysis to the effect of aggregate openness indicators on growth. Here we try to bridge theoretical propositions and empirical analysis, by explicitly considering trade structure as a determinant of growth. In this paper, we examine how the processes of economic integration between two country groups affect their specialization, and whether the composition of their exports can affect the speed of catching-up. Building on previous work (De Benedictis and Tajoli, 2007a, b), we use a particular measure to compare export structures, and we test whether different or similar export compositions affect the catching-up process, ${ }^{2}$ testing if, more than openness per se, what should matter in moving income levels closer together is a country's export pattern relative to its main partners, and examining the mechanism underlying this relationship.

The empirical exercise focuses on the Central and Eastern European countries (CEECs) and their integration into the European Union (EU). This integration process is interesting to examine for a number of reasons. The CEECs display strong dynamics both in terms of GDP and changes in trade structures. Since the very early phases of transition, the CEECs opened up significantly to trade, especially toward the EU, changing sharply both the geographic and sectoral orientation of their trade flows. Such a change was not uniform, and in a previous paper we have shown that economic integration with the EU brought about different trade structures in the CEECs (De Benedictis and Tajoli, 2007a). In the same paper, we have seen that for four CEECs the change in export composition is connected to a specific aspect of integration, the process of delocalization of production undertaken by the EU countries toward those countries, which brought about an increase in bilateral trade flows between the CEECs and the EU. Finally, those countries also experienced a catching-up process toward EU income levels, even if the distance from the EU in this respect is still very large.

Are the above-mentioned phenomena somehow related? Is similarity in export composition affecting convergence in income per capita? These are relevant questions with important policy implications, but to the best of our knowledge they do not have yet a conclusive answer. The empirical evidence for the CEECs and the EU suggests that such a correlation indeed exists and it is quite robust (De Benedictis and Tajoli, 2007b). Moving from this result, we also explore the mechanisms that might give rise to it.

\footnotetext{
${ }^{2}$ Here we do not explicitly consider income growth rates as we do not apply directly the definition of convergence of Barro and Sala-i-Martin (1995) that economies with lower levels of per capita income tend to grow faster in per capita terms. Instead, we look at relative per capita income levels or differences in income levels, indicating as catching-up the process through which economies with lower per capita income levels close the existing gap. We prefer to follow this approach because for the countries in our sample and over the relatively short time span we consider, the instability in GDP growth rates is too high to give indications about a country's long run growth path.
} 


\section{Changes in GDP and in trade structure}

\subsection{Integration and catching-up in the CEECs}

Rather than trying to assess whether a particular trade structure promotes growth in general (that is, a specific sectoral specialization, such as in Hausmann, Hwang and Rodrik, 2005), in this paper, we test whether having a similar export composition brings about income similarity within a group of countries. In other words, we take as a working hypothesis the fact that trade structure can positively or negatively influence income convergence toward a group of partner countries taken as a benchmark depending on the similarity of the countries' trade structures. Therefore the choice of the countries to examine and of their benchmark is important.

Our sample is made up of the group of candidate countries for EU-membership in the 1990s: Bulgaria, the Czech Republic, Estonia, Hungary, Latvia, Lithuania, Poland, Romania, the Slovak Republic and Slovenia. For this group of countries the choice of the EU as a benchmark was quite immediate for a number of reasons. The process of trade liberalization between these CEECs and the EU was pursued immediately after the collapse of the centralized systems in Central Europe and played a key role in the integration process of the area. Even in the very early phases of transition, when experiencing negative GDP growth rates, the CEECs shifted their trade structures to a remarkable extent, both in terms of exporting industries and in terms of trading partners - something which was not observed in non-transition countries. The CEECs and the EU signed the so-called Europe Agreements in the early 1990s, starting a process of preferential trade liberalization and phasing out of their reciprocal tariffs, so that the EU quickly became the CEECs' main export market. ${ }^{3}$ To a large extent, integration though trade flows was achieved well before the formal entry of the CEECs into the EU in 2004.

For the CEECs, the EU represented a target also in terms of standards of living, and income convergence is seen as a goal of the integration process (European Commission, 2004). Since the mid-1990s the CEECs' economies reverted to positive growth rates and started to converge toward the EU both in terms of productivity and per capita income.

As shown in Table 1, on an average the CEECs' GDP per capita is less than half that of the EU15 $(\mu=40.4)$, but it has been increasing during the observation period. The reported values of the standard deviation indicate a substantial

\footnotetext{
${ }^{3}$ It is certainly true that the relative weight of trade with different EU15 members is not the same for all the CEECs. For example, Germany is the main trade partner for most of them, but Italy is especially linked to Romania and Finland to the Baltic Republics. In spite of these differences, we preferred to use the EU as a whole as a benchmark rather than individual countries for two reasons. The EU export composition is an average of all the member countries, and it is therefore less likely to be biased in a specific direction, providing a better reference point. Furthermore, trade liberalization occurred between the CEECs and the EU as whole, giving potentially the same access to the entire EU market to the CEECs. Therefore the whole EU through economic integration is affecting the CEECs' export structure - if such an effect exists.
} 
Table 1. Distribution of GDP per capita relative to the EU15 (EU15 = 100)

\begin{tabular}{|c|c|c|c|c|c|c|c|c|c|}
\hline & \multicolumn{3}{|c|}{ 1993-2002 } & \multicolumn{3}{|c|}{ 1993-1997 } & \multicolumn{3}{|c|}{ 1998-2002 } \\
\hline & $\mu$ & $\sigma$ & Min-Max & $\mu$ & $\sigma$ & Min-Max & $\mu$ & $\sigma$ & Min-Max \\
\hline Overall & 40.4 & 13.3 & $23.1-69.0$ & 39.0 & 12.9 & $23.5-64.9$ & 41.8 & 13.6 & $23.1-69.0$ \\
\hline Between & & 13.6 & $25.5-63.9$ & & 13.4 & $26.5-62.5$ & & 14.1 & $24.3-66.9$ \\
\hline Within & & 2.6 & $34.6-46.4$ & & 1.6 & $36.0-42.3$ & & 1.5 & $39.1-45.1$ \\
\hline Tot. obs. & 100 & & & 50 & & & 50 & & \\
\hline$i$ & 10 & & & 10 & & & 10 & & \\
\hline$t$ & 10 & & & 5 & & & 5 & & \\
\hline
\end{tabular}

Note: $\mu$ is the average normalized GDP per capita of the CEECs; $\sigma$ is the standard deviation of the same variable.

Source: Our elaboration based on Eurostat data.

amount of heterogeneity in the group of countries considered. The sample shows more variation across the $i$ countries (the between variation) rather than over time $t$ (the within variation), confirming very different performances of the CEECs in this respect. If we compare the differences in GDP per capita in the first part of the period with the second half, we observe that within this group the heterogeneity tends to increase rather than decrease. This is due to the fact that the catching-up process was very uneven across countries.

The differences in catching-up rates reflect a number of factors, such as different macroeconomic policies, different investment (both domestic and foreign) rates and different rates of technological catching-up. But the different growth rates might also reflect differences in the industrial structure and in the weight of sectors related to the international specialization of countries.

As far as openness is concerned, with few exceptions the CEECs have been classified as open economies since 1990-92. ${ }^{4}$ Considering other openness indicators, such as the import and export flows over GDP, all the CEECs appear to be very open to trade, with the smallest economies being naturally the most open. However, for these countries, the comparable aggregate openness indicators hide large differences in export composition.

\subsection{An index of similarity in trade structures}

The existing literature shows that the CEECs trade patterns have changed quite dramatically since the early phases of transition: the CEECs' export structure has

\footnotetext{
${ }^{4}$ In their updating of the Sachs and Warner (1995) openness indicator, Wacziarg and Welch (2003) classify only Estonia and Romania as closed economies.
} 
moved in different directions, with some countries quickly upgrading their specialization, while other countries still lag behind (Funke and Ruhwedel, 2005; Zaghini, 2005). Normally, evidence on changes in trade structures is presented using a large number of indicators and presenting an array of sectoral specialization indices, but it is not straightforward to find a suitable description of such complex changes in a measure that can be used in empirical exercises.

In De Benedictis and Tajoli (2007b), we give evidence of such a dynamic process relying on an index of similarity in export composition for the 10 CEECs considered. Here again we start by examining the evolution of trade similarity over time - from 1993 to 2002 - measuring the distance of a country's export composition from a given benchmark, using sectors' export shares toward the EU15 internal market. We define a self-similarity index (showing how the export composition of a then future EU member changed with respect to the beginning of the transition process) and an EU-similarity index (showing how the export composition of a then future EU member changed with respect to EU export composition), using a transformation of the Bray-Curtis distance index, $d_{x y}{ }^{5}$

$$
s_{x y}=1-d_{x y}=1-\frac{\sum_{i}\left|x_{i}-y_{i}\right|}{\sum_{i}\left(x_{i}+y_{i}\right)},
$$

where $x$ and $y$ are two different countries identified by $n$ sectoral export shares (the value of exports in sector $i$ over the value of total exports toward the EU15 market), given by $x_{i}$ and $y_{i}$. In defining EU-similarity, country $x$ is a CEEC and $y$ is the EU benchmark; in defining self-similarity, country $x$ is a CEEC considered at any subsequent time period and $y$ is always the initial year considered, 1993.

The self-similarity and EU-similarity indices are presented in Table 2. In both the similarity dimensions examined, the differences across countries are remarkable. Once again, the CEECs appear as a heterogeneous group, and this is true also in terms of export structure. The three Baltic Republics represent a group on their own, as their export composition has changed the most since 1993. These countries in 1993 were very different from the EU both in terms of exports and of income per capita. They show little convergence toward the EU in terms of exports, and very different performances in terms of catching-up. Romania, Bulgaria and Slovenia are the countries whose export composition changed the least in the past decade, following a very irregular path. Bulgaria also shows divergence in its export

\footnotetext{
${ }^{5}$ The Bray-Curtis semimetric - largely used in the natural sciences - is a bounded measure, $0 \leq d_{x y} \leq 1$; it has the advantage of not increasing in the number of sectors considered, $n$; of being invariant to proportional sub-classifications of the $n$ sectors considered; it is not subject to the double-zeros paradox; it lessens the effect of the largest differences since difference in high sectoral export shares contribute the same as differences between small sectoral export shares; and it is appropriate in the presence of skewed distributions. See De Benedictis and Tajoli (2007a) for a deeper description of the index, and also Finger and Kreinin (1979) for a seminal application of the index to trade data.
} 
Table 2. Export composition of the CEECs

\begin{tabular}{|c|c|c|c|c|c|c|c|}
\hline & \multirow{2}{*}{$\begin{array}{c}\text { Self-similarity } \\
\text { index } \\
(1993=1) \\
2002 \\
\end{array}$} & \multicolumn{2}{|c|}{$\begin{array}{c}\text { EU-similarity } \\
\text { index } \\
(\text { EU15 = 1) }\end{array}$} & \multicolumn{2}{|c|}{$\begin{array}{l}\text { Relevance of } \\
\text { EU market } \\
\text { (\% of total } \\
\text { exports) }\end{array}$} & \multicolumn{2}{|c|}{$\begin{array}{c}\text { Share of } \\
\text { high-tech goods } \\
\text { over total exports } \\
\text { to EU (\%) }\end{array}$} \\
\hline & & 1993 & 2002 & 1993 & 2002 & 1993 & 2002 \\
\hline Bulgaria & 0.76 & 0.52 & 0.43 & 48.00 & 59.62 & 5.42 & 4.87 \\
\hline Czech Rep. & 0.66 & 0.65 & 0.68 & 58.60 & 67.67 & 8.81 & 17.79 \\
\hline Estonia & 0.47 & 0.30 & 0.41 & 58.11 & 81.51 & 0.67 & 24.98 \\
\hline Hungary & 0.56 & 0.61 & 0.64 & 69.38 & 69.24 & 12.11 & 30.28 \\
\hline Latvia & 0.40 & 0.23 & 0.28 & 86.92 & 80.65 & 0.67 & 7.54 \\
\hline Lithuania & 0.48 & 0.26 & 0.35 & 38.57 & 49.12 & 0.50 & 2.24 \\
\hline Poland & 0.67 & 0.52 & 0.69 & 62.66 & 64.98 & 5.64 & 13.09 \\
\hline Romania & 0.75 & 0.36 & 0.42 & 59.57 & 71.07 & 3.30 & 10.26 \\
\hline Slovakia & 0.54 & 0.48 & 0.61 & 46.88 & 63.79 & 4.03 & 13.27 \\
\hline Slovenia & 0.75 & 0.61 & 0.68 & 63.25 & 62.39 & 12.80 & 16.87 \\
\hline
\end{tabular}

Source: Our elaboration based on Eurostat data.

composition with respect to the EU, and Romania shows some convergence only in the last few years. ${ }^{6}$ The remaining five countries changed their export composition in an EU direction, though to quite different extents. Summing up, there is no generalized trend in the changes observed in the export composition, confirming that the CEECs followed different paths in restructuring their economies, just as they recorded different macroeconomic performances, and that economic integration and export composition can move in different directions.

The observation of the data on relative GDP per capita of the CEECs (Table 1) together with the changes in export structure (Table 2) might suggest a possible relationship between converging trade structures and catching-up: on average the countries whose export paths are less convergent toward the EU are also the countries lagging behind in terms of incomes. The existence of such a relationship should be tested empirically. In the rest of the paper, we develop the empirical test of this relation over the period 1993-2002 also in order to explore some of the underlying factors that bring about a positive correlation between similarity in export composition and catching-up.

\footnotetext{
${ }^{6}$ A possible explanation for this divergence is the type of delocalization of production and the derived processing trade that occurs between the EU, and Bulgaria and Romania. See De Benedictis and Tajoli (2007a).
} 


\section{Econometric analysis}

\subsection{The relationship between export composition and catching-up}

The basic expression of the regression we estimate to test the relationship between export composition and catching-up is the following:

$$
\ln G D P_{j t}=\alpha+\beta \ln \operatorname{EUSIM}_{j t}+X_{j t \gamma}+u_{j t},
$$

where $G D P_{j t}$ is per capita GDP measured using purchasing power parities in percentage of the average EU income per capita. This variable - taking values between 0 and 1 - measures directly the existing gap in per capita incomes between the CEECs and the EU at time $t$, and an increase in its value indicates that the gap is narrowing. EUSIM ${ }_{j t}$, which is our main variable of interest, is the index measuring the similarity between the CEECs and the EU export composition, and an increase in this index indicates that the trade structures are becoming more similar. If our hypothesis is valid (i.e., similarities in export composition can foster the catching-up process), the estimate of the $\beta$ coefficient should be positive and significant.

$X_{j t}$ is a vector of control variables, which include variables associated with the catching-up process in the theoretical and empirical literature. We include among regressors our index of self-similarity, which should capture the extent of the changes in the CEECs' export composition with respect to their export composition in 1993, the earliest year of transition included in the dataset. Larger changes in the export composition are measured by a lower value of the self-similarity index. The variable openness ${ }_{j t}$ measures the trade (exports + imports) share of GDP, in purchasing power parities. The other covariates influencing catching-up include investment, measured by the share of gross capital formation of GDP, the level of schooling in 1993, and a proxy for the quality of institutions, measured using the 1999 EBRD transition index (EBRD, 2000). Finally, $u_{j t}$ is an i.i.d. error term. All variables are measured in natural logs in order to facilitate comparisons of partial effects. Specific information on the data sources is presented in the Appendix.

Regression results are reported in Table 3. Our first regressions only consider the correlation between EUSIM and GDP. The estimates confirm the positive sign of the correlation between catching-up and increase similarity in EU-CEECs trade structure. The EU-similarity coefficient is significant at the 99 percent level and this variable alone explains almost 60 percent of the variance of the dependent variable. Certainly the reduction of the difference in income levels depends on a number of different factors not captured by the EU-similarity variable. Nonetheless, these first results are encouraging in indicating that the trade structure might not be irrelevant in affecting the catching-up process.

The coefficients of EUSIM in the within- and between-estimates (columns 2 and 3 of Table 3) confirm the observed countries' heterogeneity, and suggest the use of 
Table 3. Pooled data regressions: dependent variable is country's per capita GDP relative to EU's per capita GDP

\begin{tabular}{|c|c|c|c|c|c|c|}
\hline & $\begin{array}{l}\text { LS } \\
\text { (1) }\end{array}$ & $\begin{array}{l}\text { Within } \\
\text { (2) }\end{array}$ & $\begin{array}{c}\text { Between } \\
\text { (3) }\end{array}$ & $\begin{array}{l}\text { LS } \\
(4)\end{array}$ & $\begin{array}{c}\text { Within } \\
\text { (5) }\end{array}$ & $\begin{array}{c}\text { Random } \\
\text { effects } \\
\text { (6) }\end{array}$ \\
\hline Intercept & $\begin{array}{l}4.18^{* * *} \\
(0.04)\end{array}$ & $\begin{array}{l}3.98^{* * *} \\
(0.05)\end{array}$ & $\begin{array}{l}4.19^{* * *} \\
(0.17)\end{array}$ & $\begin{array}{l}2.88^{* * *} \\
(0.43)\end{array}$ & $\begin{array}{l}2.92^{* * *} \\
(0.21)\end{array}$ & $\begin{array}{l}1.55^{* *} \\
(1.11)\end{array}$ \\
\hline EU-similarity & $\begin{array}{l}0.73^{* * *} \\
(0.06)\end{array}$ & $\begin{array}{l}0.46^{* * *} \\
(0.07)\end{array}$ & $\begin{array}{l}0.75^{* * *} \\
(0.21)\end{array}$ & $\begin{array}{l}0.66^{* * *} \\
(0.06)\end{array}$ & $\begin{array}{l}0.36^{* * *} \\
(0.08)\end{array}$ & $\begin{array}{l}0.33^{* * *} \\
(0.07)\end{array}$ \\
\hline Self-similarity & & & & $\begin{array}{c}0.02 \\
(0.07)\end{array}$ & $\begin{array}{c}-0.04 \\
(0.04)\end{array}$ & $\begin{array}{c}-0.06 \\
(0.04)\end{array}$ \\
\hline Gross capital formation & & & & $\begin{array}{l}0.36^{* * *} \\
(0.07)\end{array}$ & $\begin{array}{l}0.19^{* * *} \\
(0.04)\end{array}$ & $\begin{array}{l}0.19^{* * *} \\
(0.05)\end{array}$ \\
\hline Schooling & & & & $\begin{array}{l}0.22^{* * *} \\
(0.08)\end{array}$ & & $\begin{array}{c}0.29 \\
(0.39)\end{array}$ \\
\hline Institutions & & & & $\begin{array}{l}0.65^{* * *} \\
(0.22)\end{array}$ & & $\begin{array}{l}1.41^{* *} \\
(0.92)\end{array}$ \\
\hline Openness & & & & $\begin{array}{l}0.09^{* *} \\
(0.04)\end{array}$ & $\begin{array}{l}1.14^{* * *} \\
(0.35)\end{array}$ & $\begin{array}{l}0.24^{* *} \\
(0.14)\end{array}$ \\
\hline Openness $\times$ population & & & & $\begin{array}{c}-0.02^{* * *} \\
(0.005)\end{array}$ & $\begin{array}{l}-0.12^{* * *} \\
(0.04)\end{array}$ & $\begin{array}{l}-0.02^{* *} \\
(0.01)\end{array}$ \\
\hline Obs. & 100 & 100 & 100 & 100 & 100 & 100 \\
\hline$\sigma_{e}$ & 0.20 & 0.062 & & 0.139 & 0.050 & 0.050 \\
\hline$\sigma_{u}$ & & 0.227 & & & 0.584 & 0.231 \\
\hline$R_{a d j}^{2}$ & 0.587 & 0.587 & 0.587 & 0.822 & 0.999 & 0.999 \\
\hline$F$ & $139.3^{* * *}$ & $37.71^{* * *}$ & $12.38(1.8)^{* * *}$ & $60.74^{* * *}$ & $22.21(5.85)$ & \\
\hline Hausman $\chi^{2}$ & & & & & & $16.68^{* *}$ \\
\hline
\end{tabular}

Notes: Standard errors in parentheses. All variables are in natural logs.

In this table the significance levels $0.05,0.01$ and 0.001 are indicated by the symbols ${ }^{*} * *$ and ${ }^{* *}$, respectively.

countries' fixed effects in the regression. In column 4 of Table 3, we report the estimates of a pooled least squares regression where we also introduced other control variables to capture some of these differences across countries. The sign and the significance of the variables in our control group are as expected. The share of investments over GDP, the percentage of population with secondary education in 1993 and the proxy of the quality of institutions are all positively associated with a higher rate of convergence, and in our regression they indeed appear positive 
and significant, and they improve the fit of the regression. Also, openness is positively and significantly associated with the catching-up process, especially in small countries. The openness variable interacted with population (measuring the size of the country) displays a negative sign suggesting, not surprisingly, that openness has a diminished effect in large economies. The self-similarity coefficient, capturing the extent of the change in the export composition, is statistically insignificant once the degree of openness is controlled for. The non-significance of the selfsimilarity variable - while EU-similarity maintains its significance - corroborates the conjecture that it is not a change in the export composition per se that matters for convergence, but rather the direction of change.

In column 5 of Table 3, we introduced countries' fixed effects to check for unobserved countries' characteristics in our panel. As a consequence all time-invariant variables - such as schooling and the quality of institutions - were dropped from the regression. The use of countries' fixed effects significantly improves our goodness-of-fit, and the result of a Hausman test of this last specification against the use of random effects gives support to this choice. Also in the fixed effects specification the EU-similarity variable is strongly significant in explaining the catching-up.

Estimates in column 5 of Table 3 have been checked for non-normally distributed errors, collinearity and heteroskedasticity: the regression always passed the tests. ${ }^{7}$ Again, the index of EU similarity - even changing specifications and control variables - is always positive and significant.

\subsection{The non-linear relationship between catching-up and similarity}

As in De Benedictis and Tajoli (2007b), we tested the possible non-linear effect of EUSIM on the dependent variable without imposing any particular constraint on the data in terms of specific non-linear functional form. Instead of using a tree-regression approach, as in Durlauf and Johnson (1995), we used an additive semiparametric regression, as in Liu and Stengos (1999). The semiparametric fixed-effects panel estimate has the great advantage of allowing some standard inference.

The resulting regression equation is:

$$
\ln G D P_{j t}=\alpha_{j}+g\left(\ln \operatorname{EUSIM}_{j t}\right)+X_{j t \gamma}+u_{j t} .
$$

The only difference with respect to regression (5) is that the variable EUSIM does not enter the equation linearly. Where $g$ (ln EUSIM) is an unknown function that takes the form of a smoothing spline (Hastie and Tibshirani, 1999). The smooth

\footnotetext{
${ }^{7}$ We also addressed the problem of simultaneity between openness and income levels (Frankel and Romer, 1999) instrumenting openness via a one period or two periods lag. No major changes in the coefficients or in their significance have been noticed. Since there is a strong presumption of a serial correlation in openness we also used the first difference of the variable as an instrument. In this case the magnitude of the coefficients changes, but the sign and the significance remain stable.
} 


\section{Figure 1. Marginal effect of EU-similarity on convergence}

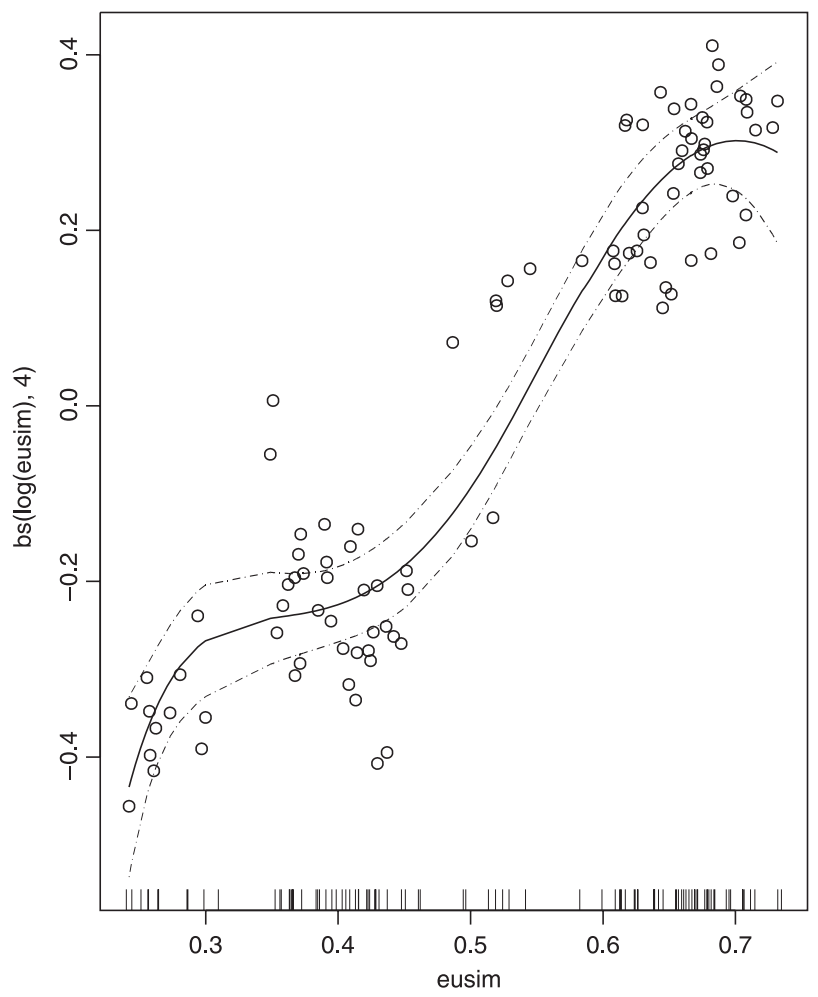

term is modelled using polynomial regression splines, ${ }^{8}$ and the semiparametric regression is estimated through a back-fitting procedure (Hastie and Tibshirani, 1999; Yatchew, 1998), to allow for comparison with a more complex semiparametric functional form with two or more non-parametric terms.

The coefficients of the covariates in column 1 of Table 5 are remarkably similar to that of regression (5) in Table 3, apart from the direct and indirect effect of openness on catching-up. Regarding the partial effect of EUSIM, the result of the semiparametric regression is plotted in Figure 1 together with $2 \sigma^{e}$ reference bands. The spikes at the base of the plot represent the frequency of observations. The evidence of a non-linear effect is significant and robust, indicating the existence of multiple regimes. Moving from the left edge of the covariate space, catching-up rapidly increases flattening down at a second stage, and rising again at high levels

\footnotetext{
${ }^{8}$ Splines are piece-wise polynomial functions that fit together at 'knots' (Hastie and Tibshirani, 1999, p. 22); for cubic splines - as in our case - the first and second derivatives are also continuous at the knots.
} 
of EU-similarity. Similarity in export composition seems to be more effective only after a certain threshold is reached. It is not so important to move 'a little bit' toward the EU export composition; what seems to matter for catching-up is to be sufficiently similar around $0.45\left(e^{-0.8}\right)$ in terms of EU-similarity.

The second main result of our analysis is that similarity in trade structure not only matters in reducing the income gap, but its effect on income convergence is magnified as similarity becomes higher. A multiple regime exists among the CEECs catching-up with the EU's per capita GDP, and being similar to the sectoral export composition of EU countries as suppliers for the EU market seems to be the discriminatory factor separating countries that are catching-up from the ones that are falling behind.

\subsection{The interaction between similarity in export composition and the growth mechanisms}

Having found robust evidence on the role of similarity in trade structures in closing the income gap for the CEECs, we now turn to the mechanisms underlying this effect. In the literature there are at least three quite different channels through which similarity in export composition might affect the process of catching-up: by enhancing the scope of technological spillovers and technological transfer; by the matching of export supply and demand; and by providing the insurance given by similar export structures. The first channel links similarity in trade structure and productivity improvements, as trade in similar or identical industries allows exploiting different externalities that can positively affect growth rates. Intra-industry trade exploits economies of scale, enhancing productivity, which can accelerate the growth rate along the transition path. Production sharing and processing trade, which are very important phenomena in the EU-CEECs trade relations and give rise to an important overlap of trade flows, increase the likelihood of spillovers and the access to advanced technology by the CEECs. Similar export patterns can also increase average productivity through increased competition for the firms involved, as suggested by Ben-David and Kimhi (2000). The effects of increased productivity are directly connected to factors' accumulation. If growth and convergence are driven by factor accumulation and incentives to accumulate depend on returns and prices (Ventura, 1997; Young, 1991), similar trade specialization brings about a similar incentive structure and can enhance the catching-up process.

If an export composition similar to the EU matters for the catching-up of a country, because this allows for more knowledge and technological spillovers through trade, we expect the weight of the sectors where such spillovers are stronger to play a positive role. Therefore, in the following regressions we use the share of high-tech goods (computers, electrical machinery, aerospace, pharmaceuticals and precision tools) in the total exports of each country to capture this effect.

Another important channel for spillovers which also tends to make export patterns more similar is outward processing trade (OPT), both in the form of intra-firm trade 
and outside the FDI channel. Through OPT, goods belonging to the same merchandise group are exported by a country to be processed abroad and then re-exported by the processing country, therefore appearing in the export vector of both. The processing of intermediate foreign goods coming from the EU15, extensively undertaken in the CEECs, is an important vehicle of technology transfer. On an empirical basis FDI and OPT are highly collinear and therefore we introduced them one at a time as covariates in the regression. Since OPT partial estimates were highly significant while FDI were not, we use only the former as a proxy for technological transfer through international production sharing.

The second channel connecting export similarity and convergence enhances the demand-side effects, rather along the lines first suggested by Linder (1961) and more recently developed by Markusen (1986). The matching of export supply and import demand allow an increase in trade volumes and the exploitation of the scale effects built in endogenous growth models (Rivera-Batiz and Romer, 1991). Therefore the positive dynamic consequences of trade are more likely to take place if the goods exported by a country are matched by a large and growing demand in its export market. The role of demand in the export market is further enhanced when export composition is driven also by delocalization of production undertaken by firms active in the same market. In this case, demand in the final destination market is a common factor influencing both the delocalization decisions and the flow of exports consequential on the delocalization process. If similarity in trade structures reflects this matching of supply and demand, a lagging country can speed up its catching-up process as long as its trade structure becomes more similar to that of advanced countries, as this will expand the opportunities offered by trade, and a dynamic demand in the main export market should enhance the catching-up process. As a proxy for the dynamics of demand in the EU market, we use the EU15 GDP growth rate.

Finally, a country having an export composition similar to the one of its trading partners enjoys an implicit form of insurance being exposed to similar business cycle phases and to shocks, reducing the number of divergence factors. ${ }^{9}$ Such an insurance through trade is more needed when other forms of insurance are missing. Therefore, to capture the importance of similarity in export composition as an insurance mechanism, we introduce a proxy of the availability of other forms of insurance, measured by an index of development of financial markets or of the banking sector.

In the last part of our empirical exercise, we introduce in the regression the additional controls related to these mechanisms, interacting them with the EUsimilarity variable. The significance of a specific interaction term indicates which channel enhances the role of similarity in export composition. The presence of

\footnotetext{
${ }^{9}$ The economic literature sees export diversification as a form of insurance against industry-specific adverse shocks (Helpman, 1988; Kalemli-Ozcan, Sorensen and Yosha, 2003; Saint-Paul, 1992) which may stop or slow down the catching-up process.
} 
Table 4. Correlation matrix

\begin{tabular}{lcccccr}
\hline & $\ln$ GDP $_{j t}$ & $\ln$ EUSIM $_{j t}$ & EU-GROWTH $_{t}$ & HIGHTECH $_{j t}$ & OPT $_{j t}$ & BANK $_{j}$ \\
\hline $\ln$ GDP $_{j t}$ & 1.0000 & & & & & \\
$\ln$ EUSIM $_{j t}$ & 0.7662 & 1.0000 & & & & \\
EU-GROWTH $_{t}$ & 0.0016 & 0.0646 & 1.0000 & & & \\
HIGHTECH $_{j t}$ & 0.6007 & 0.5976 & 0.1465 & 1.0000 & & \\
OPT $_{j t}$ & -0.4682 & -0.2017 & -0.0820 & -0.3729 & 1.0000 & \\
BANK $_{j}$ & 0.4893 & 0.3268 & -0.0000 & 0.6463 & -0.2351 & 1.0000 \\
\hline
\end{tabular}

non-linearity in the coefficient of EU-similarity suggests that interaction terms should capture these effects, giving also some indications about the channels that play a significant role.

As shown in Table 4, our proxies are weakly positively correlated with relative GDP per capita and with the EU similarity index, with the exception of OPT, displaying a negative correlation. In Table 5, we report the results of the regressions using one by one each of these control variables interacted with the EU-similarity index. It is worth noticing that our main result still holds using these interactions terms: the coefficient of the EU-similarity variable is once more significant and positive. The comparison of the different interaction terms shows that a similar export composition matters for catching-up especially when it allows exploiting the growth of demand in the export market and when OPT (a deeper form of integration) takes place. The role of EU-similarity is not driven by the growing weight of high-tech sectors, as the non-significance of the interaction term between the high-tech share in exports and EU-similarity shows.

Only when in the last regression all the interaction terms are introduced simultaneously, does the EU similarity index totally lose its significance. Our interpretation of this result is that our hypothesis about which are the main channels through which a similar export composition affects the catching-up process is confirmed.

\section{Conclusions}

Both empirical evidence and theoretical models suggest that the relationship between trade and growth might be a contingent one, depending on a host of specific circumstances. Trade models indicate that different models of specialization have diversified effects on factor prices and therefore factor accumulation, suggesting that one of the specific circumstances affecting the trade and growth relationship might indeed be the pattern of trade. In this paper, we test this hypothesis for the case of the CEECs and the EU. 
Table 5. Interactions with EU-similarity

\begin{tabular}{|c|c|c|c|c|c|c|c|}
\hline & GAM (7) & GAM (8) & GAM (9) & GAM (10) & Within (10 bis) & GAM (11) & GAM (12) \\
\hline EU-similarity & $\begin{array}{l}\text { See } \\
\text { Figure } 1 \\
(31.89)^{1}\end{array}$ & $\begin{array}{l}\text { See } \\
\text { Figure 2(a) } \\
(31.43)^{1}\end{array}$ & $\begin{array}{c}\text { See } \\
\text { Figure 2(b) } \\
(9.12)^{1}\end{array}$ & $\begin{array}{l}\text { See } \\
\text { Figure 2(c) } \\
(13.65)^{1}\end{array}$ & $\begin{array}{l}1.69^{* *} \\
(0.58)\end{array}$ & $\begin{array}{l}\text { See } \\
\text { Figure 2(d) } \\
(11.60)^{1}\end{array}$ & $\begin{array}{c}\text { See } \\
\text { Figure } 3 \\
(5.31)^{1}\end{array}$ \\
\hline Self-similarity & $\begin{array}{c}-0.06 \\
(0.04)\end{array}$ & $\begin{array}{c}-0.06 \\
(0.05)\end{array}$ & $\begin{array}{c}-0.04 \\
(0.04)\end{array}$ & $\begin{array}{c}-0.05 \\
(0.05)\end{array}$ & $\begin{array}{c}-0.03 \\
(0.04)\end{array}$ & $\begin{array}{c}-0.18^{* * *} \\
(0.05)\end{array}$ & $\begin{array}{l}-0.16^{* * *} \\
(0.05)\end{array}$ \\
\hline Gross capital formation & $\begin{array}{l}0.16^{* * *} \\
(0.04)\end{array}$ & $\begin{array}{l}0.16^{* * *} \\
(0.04)\end{array}$ & $\begin{array}{l}0.19^{* * *} \\
(0.04)\end{array}$ & $\begin{array}{l}0.17^{* * *} \\
(0.04)\end{array}$ & $\begin{array}{l}0.20^{* * *} \\
(0.04)\end{array}$ & $\begin{array}{l}0.13^{* *} \\
(0.04)\end{array}$ & $\begin{array}{l}0.15^{* * *} \\
(0.04)\end{array}$ \\
\hline Openness & $\begin{array}{l}1.45^{* * *} \\
(0.36)\end{array}$ & $\begin{array}{l}1.48^{* * *} \\
(0.41)\end{array}$ & $\begin{array}{l}1.09^{* *} \\
(0.45)\end{array}$ & $\begin{array}{l}1.48^{* * *} \\
(0.36)\end{array}$ & $\begin{array}{l}1.37^{* * *} \\
(0.35)\end{array}$ & $\begin{array}{l}1.06^{* *} \\
(0.41)\end{array}$ & $\begin{array}{c}0.83^{*} \\
(0.49)\end{array}$ \\
\hline Openness $\times$ population & $\begin{array}{l}-0.16^{* * *} \\
(0.04)\end{array}$ & $\begin{array}{c}-0.15^{* * *} \\
(0.04)\end{array}$ & $\begin{array}{l}-0.12^{* * *} \\
(0.03)\end{array}$ & $\begin{array}{l}-0.16^{* * *} \\
(0.04)\end{array}$ & $\begin{array}{c}-0.15^{\text {***}} \\
(0.04)\end{array}$ & $\begin{array}{c}-0.12^{* * *} \\
(0.04)\end{array}$ & $\begin{array}{c}-0.10^{* *} \\
(0.05)\end{array}$ \\
\hline EU-similarity $\times$ hightech & & $\begin{array}{c}0.003 \\
(0.02)\end{array}$ & & & & & $\begin{array}{r}0.001 \\
(0.02)\end{array}$ \\
\hline EU-similarity $\times$ opt & & & $\begin{array}{l}0.08^{* * *} \\
(0.002)\end{array}$ & & & & $\begin{array}{l}0.05^{* *} \\
(0.02)\end{array}$ \\
\hline EU-similarity $\times$ bank & & & & $\begin{array}{c}-0.29 \\
(0.62)\end{array}$ & $\begin{array}{c}-1.14^{* *} \\
(0.49)\end{array}$ & & $\begin{array}{c}0.16 \\
(0.69)\end{array}$ \\
\hline EU-similarity $\times$ EU-growth & & & & & & $\begin{array}{l}0.06^{* * *} \\
(0.02)\end{array}$ & $\begin{array}{l}0.05^{* * *} \\
(0.02)\end{array}$ \\
\hline Country fixed-effects & yes & yes & yes & yes & yes & yes & yes \\
\hline Obs. & 100 & 100 & 100 & 100 & 100 & 90 & 90 \\
\hline$R_{a d j}^{2}$ & 0.977 & 0.977 & 0.98 & 0.977 & 0.999 & 0.983 & 0.999 \\
\hline GCV score & 0.002 & 0.002 & 0.002 & 0.003 & & 0.002 & 0.002 \\
\hline
\end{tabular}

Notes: Standard errors in parentheses. All variables are in natural logs.

${ }^{1}$ indicates the approximate significance of smooth terms in terms of $\chi^{2}$-value.

In this table the significance levels $0.05,0.01$ and 0.001 are indicated by the symbols *** and ${ }^{* *}$, respectively. 
Figure 2. Marginal effect of EU-similarity interacted

(a)

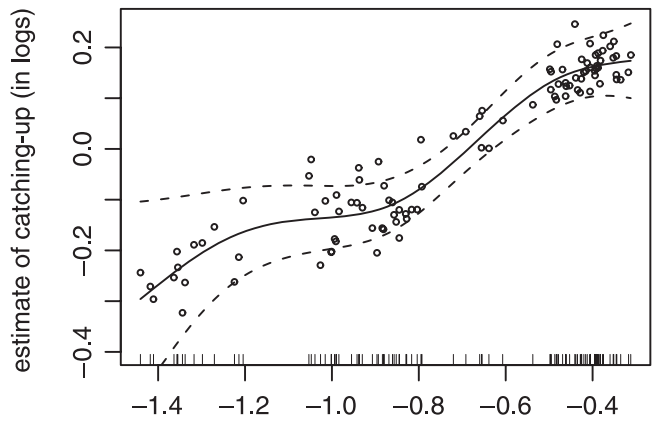

log of EU-similarity (partial effect) + hightech

(c)

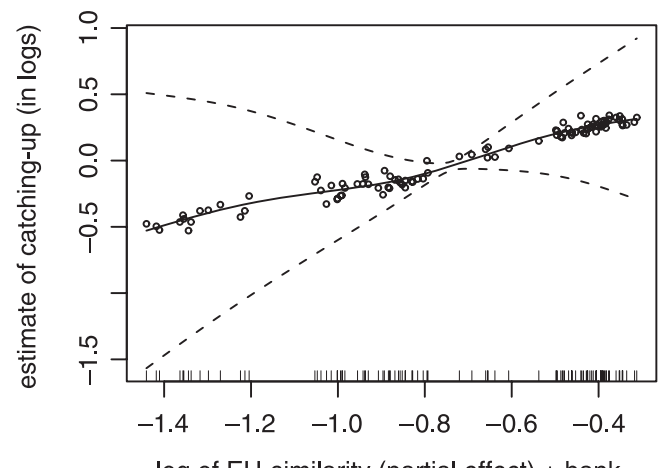

log of EU-similarity (partial effect) + bank (b)

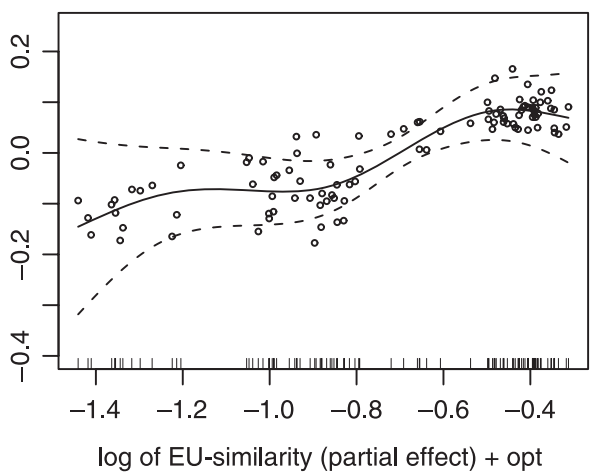

(d)

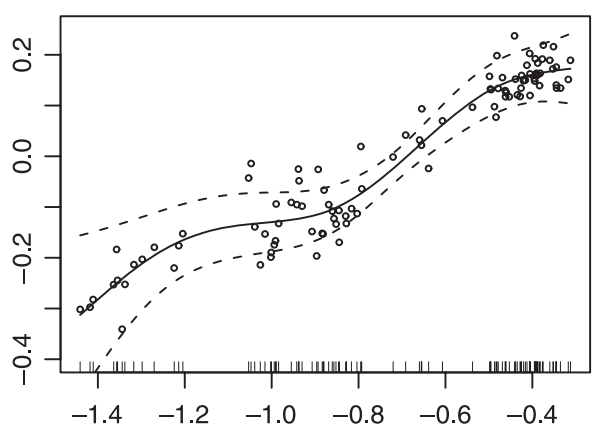

log of EU-similarity (partial effect) + EU-growth

The CEECs have been converging toward EU income levels during the 1990s at different speeds. The EU is also the main trade partner of these countries, and their export flows toward the EU market have been increasing, but these flows also displayed different characteristics. Our empirical analysis shows that a measure of export composition similarity between the CEECs and the EU is positively and significantly associated with the convergence process of these countries in terms of income: the CEECs whose export composition is closer to the EU enjoyed a faster catching-up process. Results also show that this impact is non-linear, yet it is robust controlling for investment, schooling and the quality of institutions. Theoretical analyses suggest various reasons behind this result, but the proper mechanism driving the observed link needs to be further explored. The use of variables that proxy the possible different mechanisms indicates that matching the demand of the main export market plays an important role. 
Figure 3. Marginal effect of EU-similarity in the extended model

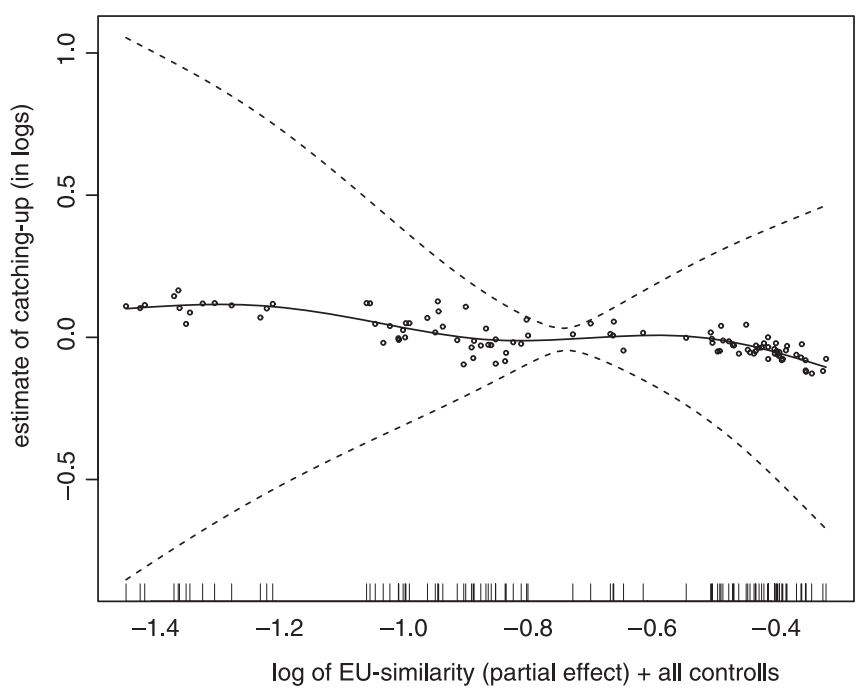

How economic integration affects convergence and catching-up between countries is a very sensitive issue. In the EU, income convergence is one of the main challenges, as wide gaps in income levels and living standards among members can put strain on the whole process of European integration. This could be true also in other circumstances of integration between countries at different stages of development. Further research could therefore also consider whether these results for the CEECs and the EU can be generalized to other episodes of economic integration.

\section{References}

Baldwin, R. E. (2004). 'Openness and growth: What is the empirical relationship?', in Baldwin, R. E. and Winters, A. (eds.), Challenges to Globalization, Chicago, IL: University of Chicago Press, pp. 499-524.

Barro, R. and Sala-i-Martin, X. (1995). Economic Growth, Cambridge, MA: MIT Press.

Ben-David, D. and Kimhi, A. (2000). 'Trade and the rate of income convergence', NBER Working Paper No. 7642, Cambridge, MA: NBER.

De Benedictis, L. and Tajoli, L. (2007a). 'Economic integration and similarity in trade structures', Empirica, 34, pp. 117-137.

De Benedictis, L. and Tajoli, L. (2007b). 'Openness, similarity in export composition, and income dynamics', Journal of International Trade and Economic Development, 16(1), pp. 93-116.

Durlauf, S. N. and Johnson, P. A. (1995). 'Multiple regimes and cross-country growth behaviour', Economic Journal, 108, pp. 383-398.

EBRD (2000). EBRD Transition Report 2000: Employment, Skills, and Transition, London: EBRD. 
European Commission (2004). The EU Economy 2004 Review, Brussels: EC.

Finger, J. M. and Kreinin, M. E. (1979). 'A measure of "export similarity" and its possible uses', Economic Journal, 89(356), pp. 905-912.

Frankel, J. and Romer, D. (1999). 'Does trade cause growth?', American Economic Review, 89, pp. 379-399.

Funke, M. and Ruhwedel, R. (2005). 'Export variety and economic growth in East European transition economies', Economics of Transition, 13(1), pp. 25-50.

Hastie, T. J. and Tibshirani, R. J. (1999). Generalized Additive Models, London: Chapman and Hall.

Hausmann, R., Hwang, J. and Rodrik, D. (2005). 'What you export matters', NBER Working Paper No. 11905, Cambridge, MA: NBER.

Helpman, E. (1988). 'Trade patterns under uncertainty with country specific shocks', Econometrica, 56(3), pp. 645-659.

Kalemli-Ozcan, S., Sorensen, B.E. and Yosha, O. (2003). 'Risk sharing and industrial specialization: Regional and international evidence', American Economic Review, 93(3), pp. 903-918.

Linder, S. (1961). An Essay on Trade and Transformation, Uppsala: Almqvist and Wiksells.

Liu, Z. and Stengos, T. (1999). 'Non-linearities in cross-country growth regressions: A semiparametric approach', Journal of Applied Econometrics, 14, pp. 527-538.

Markusen, J. R. (1986). 'Explaining the volume of trade: An eclectic approach', American Economic Review, 76(5), pp. 1002-1011.

Rivera-Batiz, L. A. and Romer, P. (1991). 'Economic integration and endogenous growth', Quarterly Journal of Economics, 106, pp. 531-555.

Sachs, J. and Warner, A. (1995). 'Economic reform and the process of global integration', Brookings Papers on Economic Activity, 1, pp. 1-118.

Saint-Paul, G. (1992). 'Technological choice, financial markets and economic development', European Economic Review, 36, pp. 763-781.

Ventura, J. (1997). 'Growth and interdependence', Quarterly Journal of Economics, 107, pp. 57-84.

Wacziarg, R. and Welch, K. H. (2003). 'Trade liberalization and growth: New evidence', NBER Working Paper No. 10152, Cambridge, MA: NBER.

Yatchew, A. (1998). 'Nonparametric regression techniques in economics', Journal of Economic Literature, 36, pp. 669-721.

Young, A. (1991). 'Learning by doing and the dynamic effects of international trade', Quarterly Journal of Economics, 106, pp. 369-405.

Zaghini, A. (2005). 'Evolution of trade patterns in the new EU member states', Economics of Transition, 13(4), pp. 629-658.

\section{Appendix}

\section{Data sources}

Export composition is calculated using data from Eurostat, Comext database on intra and extra EU trade, adopting the Combined Nomenclature classification.

Openness is calculated as exports + imports/GDP using data from Eurostat, Statistics in Focus, or alternatively is the openness dummy from Sachs and Warner (1995) updated by Wacziarg and Welch (2003). 
Income gap between the CEECs and the EU is calculated as the ratio between the CEEC GDP per capita and the average EU15 GDP per capita both in PPP, taken from Eurostat, Statistics in Focus, and Economy and Finance.

Gross capital formation is taken from Eurostat and Statistics in Focus.

Population is taken from Eurostat and Statistics in Focus.

Schooling refers to the percentage of population with secondary education in 1993 (or initial available year) and it is taken from ILO Laborsta database.

The Transition index is taken from the EBRD, Transition report 2000. 